\title{
Climatic ideotype: a possible solution for adaptation of soybean under Punjab, Pakistan climate
}

\section{Introduction}

Price of climate change will be paid by our children. Recent crops and their cropping pattern is the gift of climate change. Fluctuations in climate can increase or decrease the production of many crops. Any change in the climate could pose challenge for researchers and farmers. Several factors of climate e.g. patterns of rainfall, temperature, outbreak of diseases and pests affects food security and production of agriculture (Ali et al., 2017). In Pakistan, floods during 2010 and 2014 have increased hunger and malnutrition due to losses in crop and livestock. Thar Desert famine in 2013 have caused the death of 390 children as well as many animals due to lack in rainfall. Seasonal monsoon is also disturbed by change in climate. Change in climate results in change in carbon dioxide level which will cause change in patterns of rainfall and rise in floods, sea levels, storms and ultimately production of crops will reduce (Hartman, 2016). In 2050 , world population will increase by $1 / 3$ and the highest increase will occur in developing countries. To satisfy the expected increase in food and feed demand, production of agriculture will have to increase by $60 \%$. Due to the variation in climate change, there is dire need to change the cropping pattern and introduction of new crops worldwide.

Soybean (Glycine $\max$ L.) known as "Golden Beans" which is also called "meat that grows on plant" because its seeds contain $40 \%$ protein on an average. ${ }^{1}$ Food and agriculture organization (FAO) classified it as an oilseed crop rather than a pulse crop due to extensive use of its oil that is $20 \%$ in its seeds. ${ }^{3,4}$ Soybean is also available in the form of soy curd, soy milk, fried soy curd, soy sauce, soy oil, soy flour, fortified products of soy for women and infants, fermented soybeans and boiled soybeans. Soy is used for the treatment of diabetes, high blood pressure, heart diseases, asthma, cancer, cholesterol, weak bones, diarrhea, constipation, kidney diseases, premenstrual syndrome, menopausal symptoms and muscle soreness. ${ }^{5}$ It is a restorative crop that fixes atmospheric nitrogen. It ensures soil fertility and health when grown in rotation with exhaustive crops e.g. sugarcane, cotton and rice. Largest producer of soybean is USA followed by Brazil and Argentina. In Pakistan, soybean has potential as spring and autumn crop. Bahawalpur, Sialkot, Sargodha, Vehari, Gujranwala, Kasur, Gujrat, Jhelum, Lodhran, Multan, Attock and Khanewal are potential areas of Punjab, Pakistan for soybean cultivation. ${ }^{6}$

It was introduced in Pakistan in 1970s but area under cultivation of soybean is negligible. Sensitivity to climate changes, identification of soybean varieties for different agro-climatic zones, competition with major crops, unavailability of climate ready, high yielding, pest insect resistant varieties, absence of production technology knowledge and skills, improper marketing, weed infestation due to plantation followed by monsoon were the major bottleneck in the commercialization and production of soybeans in Pakistan. ${ }^{7}$ No work of research and experimentation have been carried out except few trails of varieties but cannot be commercialized due to production policies of other crops. ${ }^{6}$ Pakistan has imported 0.05 million tonnes soybeans from USA in January, 2015 for the month of February because of larger meal yield and better profit margins. Due to expansion in dairy, livestock, aqua culture and poultry sectors, Pakistan has imported 0.3 million tonnes of soybeans from Australia as compared to 0.06 million tonnes
Volume 2 Issue 6 - 2018

\author{
Bareera Nasir, Humera Razzaq \\ Department of Plant Breeding, University of Agriculture, \\ Faisalabad, Pakistan
}

Correspondence: Bareera Nasir, Department of Plant Breeding, University of Agriculture, Faisalabad, Pakistan, Email bareeranesir64@gmail.com

Received: August 10, 2018| Published: November 23, 2018

of canola/rapeseed in 2015. In June, 2017 import of soybean from Brazil and USA was 0.065 million tonnes which was in addition to import of 0.18 million tonnes of soybean.

Among different climatic factors temperature has severe effect on soybean germination as with $1^{\circ} \mathrm{C}$ increase in temperature, there is $99 \%$ decrease in germination. Fluctuation in temperature can decrease nitrogen fixation and nodulation in soybeans. In severely stressed plants, leaf loss can occur. ${ }^{8,9}$ Moisture stress can abort flowering and pod formation, reduce seed size, pods per plant, seed weight. This is the major cause of yield loss. Moisture stress causes spotty and uneven emergence. High relative humidity can cause deterioration of seeds. ${ }^{10}$ One percent increase in moisture content can reduce the seed longevity to half. Long distance nutrients and minerals transport is also affected by relative humidity. ${ }^{11}$ Soil fertility plays an important role in germination. ${ }^{12}$ Optimum soil $\mathrm{pH}$ for soybean is 6.0-6.5. Balanced ratio of nitrogen, potash and phosphorus requires in the soil for its growth because soybean has the ability to fix nitrogen in the soil and suck up potash and phosphorus from the soil.

There are two possible solutions to overcome the above problems. First is the characterization of soybean and it is needed due to low research work on soybeans. It is basically the description of germplasm. Expression of characters that are highly heritable is determined through characterization. It can be phenological, physiological, molecular or biochemical characterization. ${ }^{13-16}$ However, it is very expensive and time consuming. Second is the development of climatic ideotype. Donald proposed the term "Ideotype" on wheat in $1968 .{ }^{17}$ For the development of an ideotype the relationship between phenological, biochemical, molecular and physiological traits with yield is analyzed and then ideal plant type is suggested. Climatic ideotype that deals with climatic adaptation traits is suitable for the development of soybean ideotype under different agro-climatic regions. Climatic ideotype shows importance of study of variability in climate and genotypic characterization. Climatic ideotype helps to combine traits in the crop for the satisfying adaptation under variable climate under specific cropping system in specific environment. In any crop improvement program, collection of diverse germplasm acts as a building block. Selection and screening of available germplasm is a basic step after germplasm collection. Field screening under variable climatic conditions is important for the detection of suitable lines. ${ }^{18}$ Evaluation of accessions is needed for better utilization of potential 
accessions. ${ }^{19}$ Hence it is concluded that for the adaptation of soybean under Pakistan climate, Climatic ideotype development is the best possible solution and it can be done by specify certain objectives e.g. Collection of diverse germplasm, determination of genetic variability, screening of potential accessions, development of selection criteria for climatic factors and identification of potential accessions for climatic ideotype.

\section{Acknowledgments}

None.

\section{Conflicts of interest}

The author declares that there is no conflicts of interest.

\section{References}

1. Ali S, Liu y, Ishaq M, et al. Climate Change and Its Impact on the Yield of Major Food Crops: Evidence from Pakistan. Foods. 2017;6(6):39.

2. Hartman Theodore MI. Impact of Climate Change on Soybean Breeding Objectives. Meteorology Senior Theses. 2016;13:1-15.

3. Hamayun M, Khan SA, Shinwari ZK, et al. Effect of polyethylene glycol induced drought stress on physio-hormonal attributes of soybean. Pakistan J Bot. 2010;42(2):977-986.

4. Amjad M. Status of oilseed crops in Pakistan. Plant Science Division, Pakistan Agriculture Research Council, Islamabad. 2014.

5. Kusuma NB. Soybean consumption and health benefits. International J Sci and Technol Research. 2015;4(7):1-4.

6. Khurshid H, Baig D, Jan SA, et al. Miracle Crop: The Present and Future of Soybean Production in Pakistan. MOJ Biol Med. 2017;2(1):189-191.

7. Ali A, Iqbal Z, Safdar ME, et al. Comparison of yield performance of soybean varieties under semi-arid condition. J Animal and Plant Sci. 2013;23(3):828-832.

8. Tayagi SK, Tripathi RP. Effect of temperature on soybean germination.
Plant and Soil. 1983;74(2):273-280.

9. Khalil SK, Mexal JG, Rehman A, et al. Soybean mother plant exposure to temperature stress and its effect on germination under osmotic stress. Pak J Bot. 2010;42(1):213-225.

10. Meckel L, Egli DB, Phillips RE, et al. Effect of Moisture Stress on Seed Growth in Soybeans. Agronomy J. 1983;76(4):647-650.

11. Roriz M, Carvalho SMP, Vasconcelos MW. High relative air humidity influences mineral accumulation and growth in iron deficient soybean plant. Front Plant Sci. 2014;5:726.

12. Nandagawali SN. Parameters of Soil Fertility (As a part of project on soil parameters monitoring with automatic irrigation system). Int J Electrical and Electronics Research. 2015;3(4):219-222.

13. Vandana B, Shukla PS, Kamendra S, et al. Morphological characterization and assessment of genetic variability in soybean varieties. International J current microbiology and applied sciences. 2017;6(3):361-369.

14. Naik SM, Madhusudan K, Motagi BN, et al. Diversity in soybean (Glycine max) accessions based on morphological characterization and seed longevity characteristics. Progressive Research - An International Journal. 2016;11(03):377-381.

15. Al-Hadi AMG, Islam MR, Karim MA, et al. Morpho-physiological characterization of soybean genotypes under subtropical environment. Genetika. 2017;49(1):297-311.

16. Borrmann D, Junqueira RM, Sinnecker P, et al. Chemical and biochemical characterization of soybean produced under drought stress. Ciênc Tecnol Aliment. 2009;29(3).

17. Donald CM. The breeding of crop ideotypes. Euphytica. 1967;17(3):385-403.

18. Baraskar VV, Kachhadia VH, VachhanI JH, et al. Genetic variability, heritability and genetic advance in soybean [Glycine max (L.) Merrill]. Electronic J Plant Breeding. 2014;5(4):802-806.

19. Prince SJ, Murphy M, et al. Evaluation of high yielding soybean germplasm under water limitation. J Integr Plant Biol. 2016;58:475-491. 